\title{
ANALISIS FAKTOR-FAKTOR YANG BERHUBUNGAN DENGAN LOW BACK PAIN PADA PENENUN GALERY ULOS SIANIPAR MEDAN
}

\section{Evan Filemon, Gerry Silaban, Nurmaini}

Universitas Sumatera Utara (USU) Indonesia

Email: 96evanfilemon@gmail.com, gerry62fkmusu@gmail.com, nurmainik@yahoo.com

\begin{abstract}
Abstrak
Low Back Pain (LBP) atau nyeri punggung bawah merupakan salah satu keluhan kesehatan yang sering di masyarakat. Penelitian ini bertujuan untuk menganalisis hubungan faktor-faktor yang berhubungan dengan LBP pada penenun di Galery Ulos Sianipar. Sekitar 80 persen orang dewasa pernah merasakan kondisi ini. Penelitian ini adalah penelitian kuantitatif dengan pendekatan cross sectional. Penelitian dilakukan di Galery Ulos Sianipar pada bulan Agustus 2021. Populasi dalam penelitian ini adalah seluruh penenun yang bekerja di Galery Ulos Sianipar Medan sebanyak 54 orang dengan menggunakan rumus slovin diperoleh sampel sebesar 48 orang. Metode analisis data dilakukan dengan uji univariat dan bivariat, khusus untuk sikap kerja dengan metode Rapid Entire Body Assessment (REBA), dilakukan dengan bantuan kamera, busur dan lembaran kerja. Hasil penelitian menunjukkan bahwa faktor individu: umur $(\mathrm{p}=0,003)$, indeks massa tubuh $(\mathrm{p}=0,044)$ dan lama bekerja $(\mathrm{p}=0,022)$; faktor lingkungan kerja: durasi kerja $(\mathrm{p}=0,020)$ dan waktu istirahat $(\mathrm{p}=0,018)$; dan faktor pekerjaan: beban kerja $(\mathrm{p}=0,001)$ dan sikap kerja $(\mathrm{p}=0,001)$ memiliki hubungan dengan LBP pada penenun di Galery Ulos Sianipar Medan. Disarankan kepada pemilik usaha menyesuaikan letak benang pada mesin tenun dengan posisi duduk pekerja sehingga tidak mengharuskan pekerja mengangkat tangan lebih tinggi, kepada penenun disarankan untuk mengurangi atau menghindari postur janggal seperti membungkuk yang dapat menyebabkan kelelahan pada otot karena pekerjaan menenun frekuensinya sering atau berulang.
\end{abstract}

Kata Kunci: Low back pain; faktor individu; faktor lingkungan; faktor pekerjaan

\section{Abstract}

Low Back Pain (LBP) is one of the most common health complaints in the community. This study aims to analyze the relationship of factors related to LBPin weavers at the Ulos Sianipar Gallery. About 80 percent of adults have experienced this condition. This research is a quantitative research with a cross sectional approach. The study was conducted at the Ulos Sianipar Gallery in August 2021. The population in this study were all 54 weavers who worked at the Ulos Sianipar Gallery in Medan using the slovin formula, a sample of 48 people was obtained. The data analysis method was carried out using univariate and bivariate tests, specifically for work attitudes with the Rapid Entire Body Assessment (REBA)

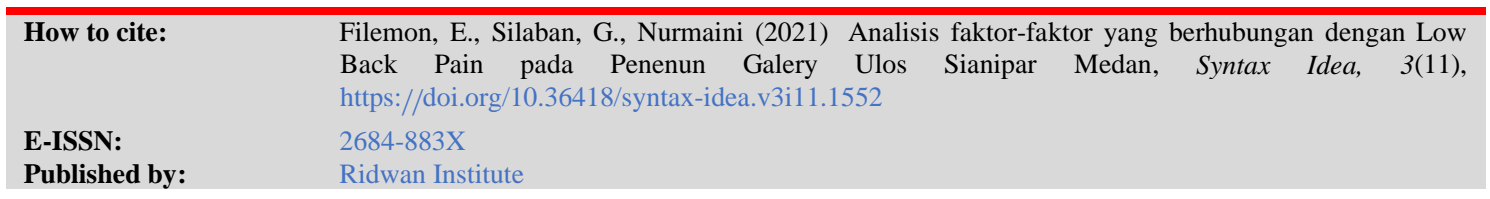


method, carried out with the help of cameras, bows and worksheets. The results showed that individual factors: age $(p=0.003)$, body mass index $(p=0.044)$ and length of work $(p=0.022)$; work environment factors: work duration $(p=0.020)$ and rest time $(p=0.018)$; and work factors: workload $(p=0.001)$ and work attitude $(p=0.001)$ have a relationship with LBP on weavers at Galery Ulos Sianipar Medan. It is recommended for business owners to adjust the position of the thread on the loom to the worker's sitting position so that it does not require workers to raise their hands higher, weavers are advised to reduce or avoid awkward postures such as bending over which can cause muscle fatigue due to frequent or repetitive weaving..

Keywords: Low back pain; individual factors; environmental factors; work factors

Received: 2021-10-22; Accepted: 2021-11-05; Published: 2021-11-20

\section{Pendahuluan}

Salah satu penyakit akibat kerja yaitu Low Back Pain (LBP) atau nyeri punggung bawah. LBP merupakan salah satu keluhan kesehatan yang lumrah di masyarakat. Sekitar 80 persen orang dewasa dikabarkan pernah merasakan keadaan ini (Sandira, 2021).

80 persen dari kita akan mengalami masalah punggung di beberapa titik dalam hidup kita. Sakit punggung menempati urutan kedua setelah sakit kepala sebagai penyebab rasa sakit yang paling sering, dan menduduki peringkat teratas dari cedera di tempat kerja, menyebabkan lebih banyak kehilangan waktu, kecacatan dan uang daripada cedera di tempat kerja lainnya. Punggung kita yaitu jaringan tulang, tendon, ligamen, dan saraf yang direkayasa dengan cermat yang membantu menyeimbangkan dan menahan beban tubuh dan beban yang kita bawa. Kerusakan atau ketidakseimbangan pada sistem yang rapuh ini bisa membuat otot dan persendian stres, menyebabkan nyeri dan cedera. Sikap tubuh yang buruk, mengangkat, menekuk dan menggapai yang buruk, dan kegiatan memutar secara bertahap dapat melemahkan susunan pendukung punggung anda serta menyebabkan rasa sakit dan cedera (Daswani, 2019).

Sebagian besar pekerja di perkantoran atau pelayanan kesehatan pemerintah, bekerja dalam posisi yang kurang ergonomis, misalnya tenaga operator peralatan, hal ini disebabkan peralatan yang digunakan pada umumnya barang impor yang disainnya tidak sesuai dengan ukuran pekerja Indonesia. Posisi kerja yang salah dan dipaksakan dapat menyebabkan mudah lelah sehingga kerja menjadi kurang efisien dan dalam jangka panjang dapat menyebabkan gangguan jasmani dan psikologis (stress) dengan keluhan yang paling sering adalah LBP (Tim K3 FT UNY, 2014).

LBP kronis sering dijumpai pada lansia, sedangkan LBP akut bisa disebabkan karena terjatuh atau kecelakaan lainnya. LBP menjadi lebih umum di antara orangorang muda yang terikat meja sepanjang hari atau mereka yang melakukan pekerjaan manual. Secara umum, LBP yang biasanya tidak melibatkan keadaan gawat ini 
disebabkan oleh postur tubuh yang buruk dan melebihi batas daya tahan otot punggung dan perut (Truong, 2020).

Dalam penelitian terdahulu tentang LBP yang dilaksanakan di Etiopia menjabarkan besarnya LBP terkait pekerjaan di kalangan industri garmen tergolong tinggi. Variabel independen seperti; Jenis kelamin, masa kerja di industri garmen, riwayat kesehatan MSD sebelumnya dan lama jam kerja per hari memiliki hubungan yang kuat dengan LBP. Akan tetapi pekerja laki-laki lebih rentan mengalami LBP dibandingkan pekerja perempuan di industri garmen, hal ini bertentangan dengan penelitian yang dilakukan di sektor lain yang sejenis sehingga diperlukan penelitian lebih lanjut untuk menyelidiki lebih lanjut (Tafese et al., 2018).

Kasus LBP bukanlah permasalahan baru. Di Indonesia, angka prevalensi kejadian LBP belum tentu pasti, namun diperkirakan banyak warga terdampak antara 7,6-37 persen dari populasi ("Kasus Low Back Pain Perlu Perhatian Khusus," 2014). Berdasarkan sebuah penelitian LBP di Bandung, Jawa Barat menjabarkan faktor risiko LBP terjadi pada ibu rumah tangga yakni sikap berdiri lebih banyak pada durasi bekerja lebih dari delapan jam, riwayat pernah bekerja sebelumnya, dan masa kerja 5-10 tahun (Nugraha et al., 2020).

Sebuah penelitian LBP di sebuah usaha penjahitan di Provinsi Jawa Tengah menunjukkan ada hubungan lama duduk dan sikap duduk terhadap keluhan LBP pada penjahit rumahan di Kecamatan Tasikmadu yakni dalam uji Spearman sebesar 0,000 dan 0,038. Tingkat hubungan antara lama duduk pada keluhan LBP lebih rendah ketimbang sikap duduk pada keluhan LBP. Dari kedua hubungan diatas bisa dikatakan bahwa lebih berhubungan lama duduk daripada sikap duduk terhadap keluhan LBP. Dikarenakan nilai Correlation Coefficient-nya lebih besar yaitu 0,713>0,334. Semakin lama ataupun semakin salah dalam melakukan kegiatan menjahit baik waktu menjahit juga sikap dalam menjahit maka akan semakin mempengaruhi keluhan LBP (Rachmat et al., 2019).

Membuat keadaan kerja yang sehat dan aman adalah kepentingan pekerja, pengusaha dan pemerintah, serta masyarakat luas. Meski tampak sederhana dan jelas, gagasan ini belum mendapatkan pengakuan yang berarti. Ratusan juta orang di seluruh dunia saat ini dipekerjakan dalam keadaan yang berkembang biak dengan kesehatan buruk dan/atau tidak aman. Setiap tahun, cedera dan penyakit terkait pekerjaan menewaskan sekitar dua juta orang di seluruh dunia, lebih besar dari jumlah kematian tahunan global akibat malaria. Setiap tahun, diperkirakan 160 juta kasus baru penyakit terkait pekerjaan terjadi di seluruh dunia, termasuk penyakit pernapasan dan kardiovaskular, kanker, gangguan pendengaran, gangguan muskuloskeletal dan reproduksi, penyakit mental dan neurologis (Lambak, 2017).

Dari beberapa penelitian di atas menunjukkan bahwa pekerjaan yang memerlukan waktu lama untuk berdiri, mengangkat, dan menggendong lebih rentan terhadap sakit punggung; sedangkan, pekerjaan yang membutuhkan tugas manual yang berulang lebih rentan terhadap nyeri ekstremitas atas yang melibatkan bahu, siku, pergelangan tangan, dan tangan. 
Salah satu usaha busana di Kota Medan saat ini ialah Galery Ulos Sianipar. Pertenunan dan Galery Ulos Sianipar merupakan usaha yang bergerak di bidang tekstil. Khususnya dalam pembuatan ulos dan songket adat bangsa Batak. Usaha Mikro, Kecil, dan Menengah (UMKM) ini telah berdiri sejak 28 Juni 1992 (Anggraini, 2019). Tidak hanya kain ulos, ada juga berbagai cinderamata yang dijual di galeri ini contohnya cemilan, kopi dan berbagai pernak-pernik lainnya dengan harga yang nisbi sesuai kebutuhan. Kain ulos beragam corak ini yang paling digemari pengunjung adalah corak sadum (Zulfiani, 2019).

Berdasarkan hasil observasi pendahuluan di tempat kerja tenun ulos di Galery Ulos Sianipar Medan terhadap delapan orang pekerja penenun ulos yang ditemui pada saat istirahat, lima orang diantaranya menyatakan pernah mengalami LBP. LBP yang dialami pekerja utamanya dirasakan setelah melakukan pekerjaan. Mayoritas pekerja mengeluh di daerah punggung yang terasa nyeri, pegal, linu, ngilu dan rasa tidak enak pada daerah punggung bawah. Keadaan tersebut tentunya bisa menurunkan efisiensi, efektivitas kerja serta pekerja tidak merasa lebih aman dan nyaman dalam bekerja sehingga dapat menyebabkan peluang kesalahan dalam melakukan pekerjaan semakin besar sehingga dapat mempengaruhi produktivitas pekerja.

Pekerjaan menenun ini melalui beberapa tahap pekerjaan mulai dari pembuatan benang (proses pemintalan kapas), pewarnaan (untuk mendapatkan warna), gatip (rangkaian grafis bercorak khusus), unggas (pencerahan benang), ani (benang yang sudah selesai diunggas), dan selanjutnya tonun (tenun) yaitu proses pembentukan benang yang sudah "diani" menjadi sehelai ulos. Hasil observasi ditemui pekerjaan menenun tersebut semuanya dilakukan dalam kondisi duduk. Bekerja dengan keadaan yang sangat tidak ergonomis, yaitu bekerja dalam posisi duduk dalam jangka waktu yang lama. Penenun kerap membungkukkan punggungnya saat menenun dan tidak dalam posisi tegak sehingga hal itu berlanjut sekian lama dan menimbulkan nyeri dipunggungnya. Penenun masing-masing mengaku bahwa mereka sering merasa pegalpegal, nyeri pada bagian pinggang, punggung, leher, bahu, paha, betis bagian depan (tibia), lengan atas dan bawah setelah melakukan serangkaian kegiatan menenun yang dilakukan baik secara jongkok, dan membungkuk dalam waktu yang lama.

Semua tahapan pekerjaan dilakukan dengan mempertahankan posisinya tanpa bergerak yang terkadang terlihat canggung dan tidak alamiah untuk mendapatkan hasil yang maksimal, berbagai risikopun dapat dialami diantaranya nyeri otot dan sendi. Berdasarkan hal tersebut, maka peneliti tertarik untuk melakukan penelitian tentang analisis faktor-faktor yang berhubungan dengan LBP pada Penenun Galery Ulos Sianipar Medan.

Manfaat dari penelitian ini adalah sebagai bahan masukan bagi pengelola dan pekerja di Galery Ulos Sianipar untuk lebih memperhatikan akan bahaya dan risiko LBP bagi pekerja. Selain itu bagi para mahasiswa/i, dapat dijadikan sebagai bahan pembelajaran di saat mereka hendak meneliti LBP di tempat-tempat pertenunan dan penjualan. 


\section{Metode Penelitian}

Penelitian ini merupakan penelitian kuantitatif dengan menggunakan pendekatan cross sectional yang menekankan pada proses pengambilan data variabel independen dan dependen pada satu saat tertentu (Sastroasmoro, S., \& Ismael, 2016). Penelitian ini menggunakan metode survei dengan memakai kuesioner mengenai faktor penyebab LBP pada penenun Galery Ulos Sianipar Medan Tahun 2021.

Penelitian ini dilakukan di Galery Ulos Sianipar Jalan A.R. Hakim Gang Pendidikan No. 130 Medan pada bulan Agustus 2021.

Populasi. Populasi adalah wilayah generalisasi yang terdiri atas: obyek/subyek yang mempunyai kualitas dan karakteristik tertentu yang ditetapkan oleh peneliti untuk dipelajari dan kemudian ditarik kesimpulannya (Sugiyono, 2013). Populasi dalam penelitian ini adalah seluruh penenun tetap yang bekerja di Galery Ulos Sianipar Medan berjumlah 54 orang dengan sampel sebanyak 48 responden.

Variabel dalam penelitian ini terdiri dari variabel independen yaitu faktor individu (usia, masa kerja, dan IMT), faktor lingkungan (durasi menenun dan waktu istirahat), faktor pekerjaan (beban kerja dan sikap dalam bekerja) dan variabel dependen yaitu Low Back Pain (LBP).

Pengolahan data dilakukan dengan SPSS 21 dengan menggunakan uji analisis univariat untuk mendapatkan gambaran tentang distribusi frekuensi responden dan bivariat untuk mengetahui hubungan variabel independen dan variabel dependen dengan memakai uji chi square pada tingkat kepercayaan 95 persen $(\mathrm{p}<0,05)$.

\section{Hasil dan Pembahasan}

\section{A. Hasil Penelitian}

\section{a. Univariat}

Analisis univariat bertujuan untuk mendapatkan gambaran distribusi ataupun besarnya proporsi masing-masing variabel yang diteliti dengan menggunakan tabel distribusi frekuensi. Sampel dalam penelitian ini adalah seluruh penenun yang bekerja di Galery Ulos Sianipar Medan sebanyak 14 orang.

Faktor Individu. Berdasarkan distribusi faktor individu pekerja yang bekerja di Galery Ulos Sianipar Medan yaitu usia, terbagi dalam tiga kelompok usia yaitu kelompok usia 25 sampai dengan 38 tahun, kelompok usia 39 sampai dengan 52 tahun dan kelompok usia 53 sampai dengan 65 tahun. Menurut pembagian kelompok tersebut penenun yang bekerja di Galery Ulos Sianipar Medan yang berada dalam kelompok usia 25 sampai 38 tahun ada enam penenun $(12,5 \%)$, kelompok umur 39 sampai dengan 52 tahun yaitu sebanyak 39 penenun $(81,3 \%)$ dan kelompok umur 53 tahun sampai dengan 65 tahun ada tiga penenun (6,3\%). Dapat dilihat pada tabel berikut ini: 
Tabel 1

Distribusi Penenun Berdasarkan Faktor Individu yaitu Umur Pekerja di Galery Ulos Sianipar Medan

\begin{tabular}{cccc}
\hline No. & Umur & n & \% \\
\hline 1 & $25-38$ tahun & 6 & 12,5 \\
2 & $39-52$ tahun & 39 & 81,3 \\
3 & $53-65$ tahun & 3 & 6,3 \\
\hline & Total & $\mathbf{4 8}$ & $\mathbf{1 0 0 , 0}$
\end{tabular}

Sumber Data: Hasil Olah Data SPSS versi 21, Tahun 2021

Distribusi penenun yang bekerja di Galery Ulos Sianipar Medan berdasarkan faktor individu yaitu IMT terbagi dalam dua kelompok yaitu berisiko dan tidak berisiko. pada kelompok IMT berisiko ada sepuluh penenun $(20,8 \%)$ sedangkan kelompok IMT tidak berisiko sebanyak 38 penenun $(79,2 \%)$. Dapat dilihat pada tabel berikut ini:

Tabel 2

Distribusi Penenun Berdasarkan Faktor Individu yaitu IMT pada Pekerja di Galery Ulos Sianipar Medan

\begin{tabular}{cccc}
\hline No. & IMT & $\mathbf{n}$ & $\boldsymbol{\%}$ \\
\hline 1 & Berisiko: & 10 & 20,8 \\
2 & Tidak berisiko & 38 & 79,2 \\
3 & Total & $\mathbf{4 8}$ & $\mathbf{1 0 0 , 0}$ \\
\hline
\end{tabular}

Sumber Data: Hasil Olah Data SPSS versi 21, Tahun 2021

Distribusi penenun yang bekerja di Galery Ulos Sianipar Medan berdasarkan faktor individu yaitu lama bekerja terbagi dalam tiga kelompok yaitu kurang dari lima tahun, lima sampai dengan 10 tahun dan lebih dari 10 tahun. pada kelompok lama bekerja kurang dari lima tahun ada delapan penenun (16,7\%), kelompok lama bekerja lima sampai dengan 10 tahun sebanyak 19 penenun $(39,6 \%)$ dan kelompok lama bekerja lebih dari 10 tahun ada 21 penenun $(43,8 \%)$. Dapat dilihat pada tabel berikut ini:

Tabel 3

Distribusi Penenun Berdasarkan Faktor Individu yaitu Lama Bekerja Pekerja di Galery Ulos Sianipar Medan

\begin{tabular}{|c|c|c|c|}
\hline No. & Lama Bekerja & $\mathbf{n}$ & $\%$ \\
\hline 1 & $<5$ tahun & 8 & 16,7 \\
\hline 2 & 5-10 tahun & 19 & 39,6 \\
\hline 3 & $>10$ tahun & 21 & 43,8 \\
\hline & Total & 48 & 100,0 \\
\hline
\end{tabular}

Sumber Data: Hasil Olah Data SPSS versi 21, Tahun 2021

Faktor Lingkungan. Distribusi penenun di Galery Ulos Sianipar Medan berdasarkan faktor lingkungan yaitu durasi kerja terbagi dalam dua kelompok 
yaitu kurang dari delapan jam perhari dan lebih sama dengan delapan jam perhari. pada kelompok kurang dari delapan jam perhari terdapat 17 penenun $(35,4 \%)$ sedangkan pada kelompok lebih sama dengan delapan jam perhari sebanyak 31 penenun $(64,6 \%)$ bisa dilihat pada tabel berikut ini:

Tabel 4

Distribusi Penenun Berdasarkan Faktor Lingkungan yaitu Durasi Bekerja di Galery Ulos Sianipar Medan

\begin{tabular}{cccc}
\hline No. & Durasi Bekerja & n & \% \\
\hline 1 & $<8$ jam/hari & 17 & 35,4 \\
2 & $\geq 8$ jam/hari & 31 & 64,6 \\
\hline & Total & $\mathbf{4 8}$ & $\mathbf{1 0 0 , 0}$
\end{tabular}

Sumber Data: Hasil Olah Data SPSS versi 21, Tahun 2021

Distribusi penenun di Galery Ulos Sianipar Medan berdasarkan faktor lingkungan yaitu waktu istirahat terbagi dalam dua kelompok yaitu kurang dari 30 menit dan lebih sama dengan 30 menit. pada kelompok kurang dari 30 menit ada sembilan penenun $(18,8 \%)$ sedangkan pada kelompok lebih sama dengan 30 menit sebanyak 39 penenun $(81,3 \%)$. Dapat dilihat pada tabel berikut ini:

Tabel 5

Distribusi Penenun Berdasarkan Faktor Lingkungan Waktu Istirahat di Galery Ulos Sianipar Medan

\begin{tabular}{cccc}
\hline No. & Waktu Istirahat & $\mathbf{n}$ & \% \\
\hline 1 & $<30$ menit & 9 & 18,8 \\
2 & $\geq 30$ menit & 39 & 81,3 \\
\hline & Total & $\mathbf{4 8}$ & $\mathbf{1 0 0 , 0}$ \\
\hline
\end{tabular}

Sumber Data: Hasil Olah Data SPSS versi 21, Tahun 2021

Faktor Pekerjaan. Distribusi penenun di Galery Ulos Sianipar Medan berdasarkan faktor pekerjaan yaitu beban kerja, terbagi dalam tiga kelompok yaitu kelompok kurang dari lima kg, kelompok lima sampai dengan $10 \mathrm{~kg}$, dan kelompok lebih dari $10 \mathrm{~kg}$. pada kelompok kurang dari lima $\mathrm{kg}$ ada delapan penenun $(16,7 \%)$, sedangkan kelompok lima sampai dengan $10 \mathrm{~kg}$ sebanyak 40 penenun $(83,3 \%)$ dan tidak ada penenun yang memiliki beban kerja lebih dari 10 kg. Dapat dilihat pada tabel berikut ini: 
Tabel 6

Distribusi Penenun Berdasarkan Faktor Pekerjaan yaitu Beban Kerja di Galery Ulos Sianipar Medan

\begin{tabular}{cccc}
\hline No. & Beban Kerja & $\mathbf{n}$ & $\mathbf{\%}$ \\
\hline 1 & $<5 \mathrm{~kg}$ & 8 & 16,7 \\
2 & $5-10 \mathrm{~kg}$ & 40 & 83,3 \\
3 & $>10 \mathrm{~kg}$ & 0 & 0,0 \\
\hline & Total & $\mathbf{4 8}$ & $\mathbf{1 0 0 , 0}$ \\
\hline
\end{tabular}

Sumber Data: Hasil Olah Data SPSS versi 21, Tahun 2021

Distribusi penenun di Galery Ulos Sianipar Medan berdasarkan faktor lingkungan yaitu sikap kerja. Dengan menggunakan metode REBA sikap kerja terbagi dalam lima kelompok yaitu risiko sangat rendah, risiko rendah, risiko sedang, risiko tinggi dan risiko sangat tinggi. Hasil penelitian menunjukkan tidak ada penenun dengan risiko sangat rendah, kelompok risiko rendah ada sepuluh penenun $(20,8 \%)$, risiko sedang sebanyak 26 penenun $(54,2 \%)$, risiko tinggi adasepuluh penenun $(20,8 \%)$ dan risiko sangat tinggi ada duapenenun (4,2\%. Dapat dilihat pada tabel berikut ini:

Tabel 7

Distribusi Penenun Berdasarkan Faktor Pekerjaan yaitu Sikap Kerja di Galery Ulos Sianipar Medan

\begin{tabular}{|c|c|c|c|}
\hline No. & Sikap Kerja & $\mathbf{n}$ & $\%$ \\
\hline 1 & Risiko Sangat Rendah & 0 & 0,0 \\
\hline 2 & Risiko Rendah & 10 & 20,8 \\
\hline 3 & Risiko Sedang & 26 & 54,2 \\
\hline 4 & Risiko Tinggi & 10 & 20,8 \\
\hline \multirow[t]{2}{*}{5} & Risiko Sangat Tinggi & 2 & 4,2 \\
\hline & Total & 48 & 100,0 \\
\hline
\end{tabular}

Sumber Data: Hasil Olah Data SPSS versi 21, Tahun 2021

Keluhan LBP. Distribusi penenun di Galery Ulos Sianipar Medan berdasarkan keluhan LBP terbagi dalam lima kelompok yaitu tidak nyeri, nyeri ringan, nyeri sedang, nyeri berat terkendali dan nyeri berat tidak terkendali. pada kelompok tidak nyeri sebanyak 11 penenun $(22,9 \%)$, nyeri ringan sebanyak 19 penenun $(39,6 \%)$, nyeri sedang sebanyak 17 penenun $(35,4 \%)$, nyeri berat terkendali ada satu penenun $(2,1 \%)$, dan tidak ada penenun dengan nyeri berat tidak terkendali bisa dilihat pada tabel berikut ini: 
Tabel 8

Distribusi Penenun Berdasarkan Keluhan LBP pada Pekerja di Galery Ulos Sianipar Medan

\begin{tabular}{cccc}
\hline No. & Keluhan LBP & n & \% \\
\hline 1 & Tidak nyeri & 11 & 22,9 \\
2 & Nyeri ringan & 19 & 39,6 \\
3 & Nyeri Sedang & 17 & 35,4 \\
4 & Nyeri Berat Terkendali & 1 & 2,1 \\
5 & Nyeri Berat Tidak Terkendali & 0 & 0,0 \\
\hline \multicolumn{4}{r}{} \\
\hline
\end{tabular}

Sumber Data: Hasil Olah Data SPSS versi 21, Tahun 2021

\section{b. Bivariat}

Analisa bivariat dalam penelitian ini digunakan untuk mengetahui faktorfaktor yang berhubungan dengan LBP pada penenun di Galery Ulos Sianipar Medan. Hasil analisis pada penelitian ini menggunakan uji chi square pada taraf signifikan $\mathrm{p}<0,05$.

Faktor Individu (Usia, Masa Kerja, dan IMT) dengan LBP pada Penenun Galery Ulos Sianipar Medan. Berdasarkan distribusi faktor individu penenun yang bekerja di Galery Ulos Sianipar Medanyaitu umur, sebagian besar dari kelompok umur 39 sampai dengan 52 tahun yaitu sebanyak 39 penenun $(81,3 \%)$ mengalami nyeri ringan dan nyeri sedang yaitu masing-masing sebanyak 16 penenun (33,3\%). Analisis statistik menunjukkan p-value sebesar 0,003 $(\mathrm{p}<0,05)$, artinya ada hubungan usia terhadap LBP pada penenun di Galery Ulos Sianipar Medan.

IMT menunjukkan bahwa sebagian besar penenun di Galery Ulos Sianipar Medan tidak berisiko sebanyak 38 penenun $(79,2 \%)$ mengalami nyeri ringan yaitu sebanyak 17 penenun (35,4\%). Analisis statistik menunjukkan p-value sebesar 0,044 ( $\mathrm{p}<0,05)$, artinya ada hubungan IMT terhadap LBP pada penenun di Galery Ulos Sianipar Medan.

Lama bekerja menunjukkan bahwa sebagian besar penenun di Galery Ulos Sianipar Medan bekerja lebih dari 10 tahun yaitu sebanyak 21 penenun $(43,8 \%)$ mengalami nyeri sedang sebanyak 11 penenun (22,9\%). Analisis statistik menunjukkan $\mathrm{p}$-value sebesar $0,022(\mathrm{p}<0,05)$, artinya ada hubungan lama bekerja pada LBP pada penenun di Galery Ulos Sianipar Medan.

Distribusi penenun berdasarkan faktor individu (usia, masa kerja, dan IMT) dengan LBP pada Penenun Galery Ulos Sianipar Medan dapat dilihat pada tabel berikut ini: 
Tabel 9

Distribusi Hubungan Faktor Individu (Usia, Masa Kerja, dan IMT) dengan

LBP pada Penenun Galery Ulos Sianipar Medan



Sumber Data: Hasil Olah Data SPSS versi 21, Tahun 2021

Dari tabel 9 bisa disimpulkan bahwa faktor individu yaitu usia, IMT dan lama bekerja berhubungan dengan LBP pada penenun di Galery Ulos Sianipar Medan.

Faktor Lingkungan Kerja yaitu Durasi Kerja dan Waktu Istirahat dengan LBP pada Penenun Galery Ulos Sianipar Medan. Berdasarkan distribusi faktor lingkungan kerja di Galery Ulos Sianipar Medan yaitu durasi kerja menunjukkan bahwa sebagian besar penenun sebanyak 31 penenun $(64,6 \%)$ bekerja lebih dari delapan jam perhari mengalami nyeri sedang sebanyak 15 penenun $(31,3 \%)$. Analisis statistik menunjukkan p-value sebesar 0,020 ( $\mathrm{p}<0,05)$, artinya ada hubungan durasi kerja terhadap LBP pada penenun di Galery Ulos Sianipar Medan. Waktu istirahat menunjukkan bahwa sebagian besar penenun beristirahat lebih dari 30 menit yaitu sebanyak 39 penenun $(81,3 \%)$ mengalami nyeri ringan yaitu sebanyak 19 penenun $(39,6 \%)$. Analisis statistik menunjukkan p-value sebesar 0,018 $(\mathrm{p}<0,05)$, artinya ada hubungan waktu istirahat pada LBP pada penenun di Galery Ulos Sianipar Medan bisa dilihat pada tabel berikut: 
Tabel 10

Distribusi Hubungan Faktor Lingkungan Kerja yaitu Durasi Kerja dan Waktu Istirahat dengan LBP pada Penenun Galery Ulos Sianipar Medan

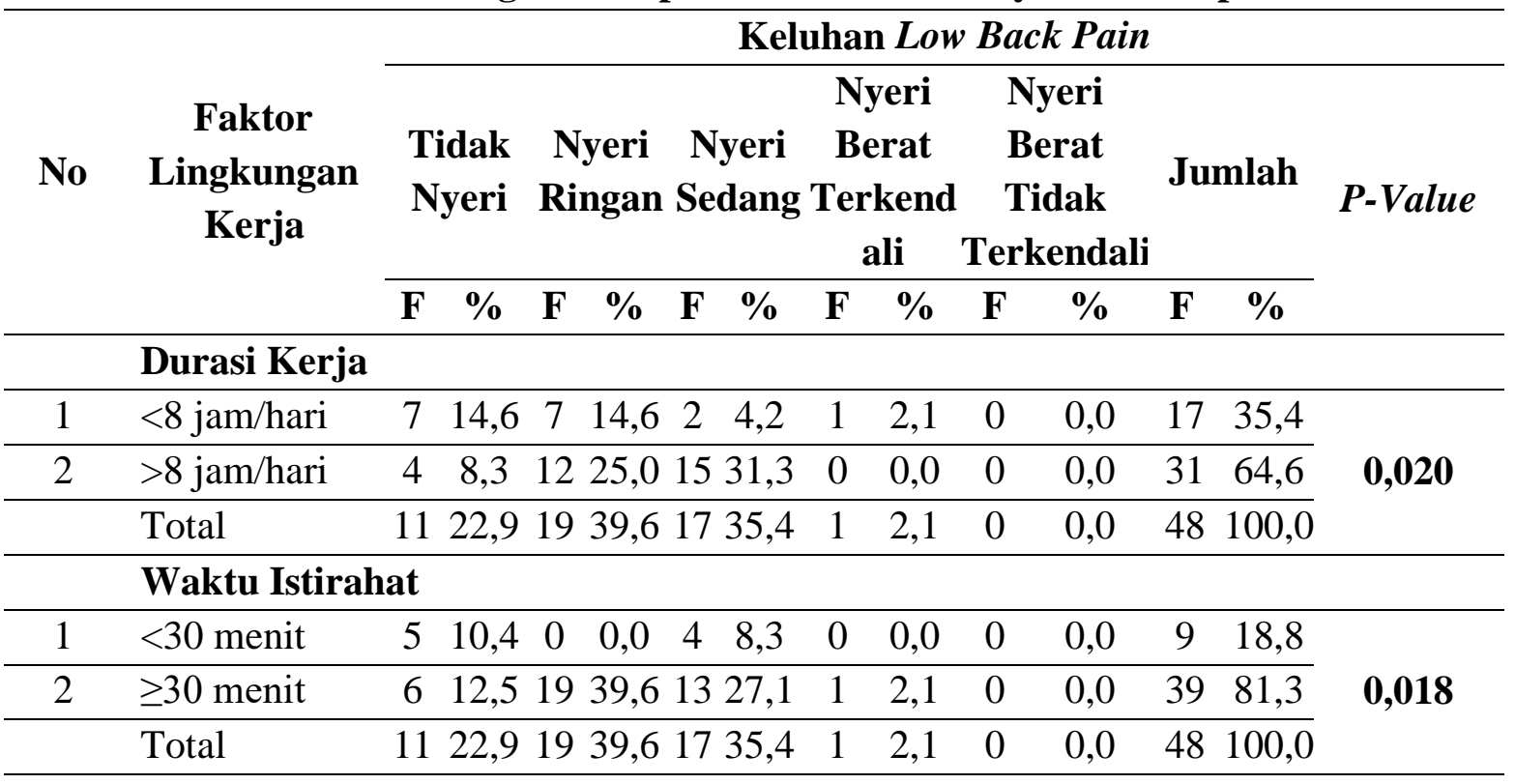

Sumber Data: Hasil Olah Data SPSS versi 21, Tahun 2021

Dari tabel 10 bisa disimpulkan bahwa faktor lingkungan kerja yaitu waktu istirahat dan durasi memiliki hubungan dengan LBP pada penenun di Galery Ulos Sianipar Medan.

Faktor Pekerjaan (Beban Kerja Dan Sikap Kerja) dengan LBP pada Penenun Galery Ulos Sianipar Medan. Berdasarkan distribusi faktor pekerjaan kerja di Galery Ulos Sianipar Medan yaitu beban kerja menunjukkan bahwa sebagian besar penenun bekerja dengan beban kerja lima sampai dengan $10 \mathrm{~kg}$ yaitu sebanyak 40 penenun $(83,3 \%)$ mengalami nyeri ringan dan nyeri sedang masing-masing sebanyak 17 penenun $(35,4 \%)$. Analisis statistik menunjukkan pvalue sebesar 0,001 $(\mathrm{p}<0,05)$, artinya ada hubungan beban kerja terhadap LBP pada penenun di Galery Ulos Sianipar Medan. Sikap kerja menunjukkan bahwa sebagian besar penenun dengan risiko sedang yaitu sebanyak 26 penenun (54,2\%) mengalami nyeri ringan sebanyak 14 penenun (29,2\%). Analisis statistik menunjukkan $\mathrm{p}$-value sebesar 0,001 ( $\mathrm{p}<0,05)$, artinya ada hubungan sikap kerja terhadap metode REBA terhadap LBP pada penenun di Galery Ulos Sianipar Medan. Dapat dilihat pada tabel berikut: 
Tabel 11

Distribusi Hubungan Faktor Pekerjaan (Beban Kerja dan Sikap Kerja) dengan LBP pada Penenun Galery Ulos Sianipar Medan

\begin{tabular}{|c|c|c|c|c|c|c|c|c|c|c|c|c|c|}
\hline \multirow{3}{*}{ No } & \multirow{3}{*}{ Faktor Pekerjaan } & \multicolumn{12}{|c|}{ Keluhan LBP } \\
\hline & & $\begin{array}{l}\text { Tidak } \\
\text { Nyeri }\end{array}$ & \multicolumn{2}{|c|}{$\begin{array}{l}\text { Nyeri } \\
\text { Ringan }\end{array}$} & \multicolumn{2}{|c|}{$\begin{array}{c}\text { Nyeri } \\
\text { Sedang }\end{array}$} & \multicolumn{2}{|c|}{$\begin{array}{c}\text { Nyeri } \\
\text { Berat } \\
\text { Terkend } \\
\text { ali }\end{array}$} & \multicolumn{2}{|c|}{$\begin{array}{c}\text { Nyeri } \\
\text { Berat } \\
\text { Tidak } \\
\text { Terkenda } \\
\quad \text { li }\end{array}$} & \multicolumn{2}{|c|}{ Jumlah } & \multirow[t]{2}{*}{ P-Value } \\
\hline & & F \% & $\mathbf{F}$ & $\%$ & $\mathbf{F}$ & $\%$ & $\mathbf{F}$ & $\%$ & $\mathbf{F}$ & $\%$ & $\mathbf{F}$ & $\%$ & \\
\hline & \multicolumn{13}{|c|}{ Beban Kerja } \\
\hline 1 & $<5 \mathrm{~kg}$ & 612,5 & 2 & 4,2 & 0 & 0,0 & 0 & 0,0 & 0 & 0,0 & 8 & 16,7 & \multirow{3}{*}{0,001} \\
\hline \multirow[t]{3}{*}{2} & $5-10 \mathrm{~kg}$ & $\begin{array}{ll}5 & 10,4 \\
\end{array}$ & 17 & 35,4 & 17 & 35,4 & 1 & 2,1 & 0 & 0,0 & 40 & 83,3 & \\
\hline & Total & 1122,9 & 19 & 39,6 & 17 & 35,4 & 1 & 2,1 & 0 & 0,0 & 48 & 100,0 & \\
\hline & \multicolumn{13}{|c|}{ Sikap Kerja } \\
\hline 1 & Risiko Sangat Rendah & $0 \quad 0,0$ & 0 & 0,0 & 0 & 0,0 & 0 & 0,0 & 0 & 0,0 & 0 & 0,0 & \multirow{5}{*}{0,001} \\
\hline 2 & Risiko Rendah & 714,6 & 3 & 6.3 & 0 & 0,0 & 0 & 0,0 & 0 & 0,0 & 10 & 20,8 & \\
\hline 3 & Risiko Sedang & $\begin{array}{ll}3 & 6.3 \\
\end{array}$ & 14 & 29,2 & 9 & 18,8 & 0 & 0,0 & 0 & 0,0 & 26 & 54,2 & \\
\hline 4 & Risiko Tinggi & 12,1 & 2 & 4,2 & 6 & 12,5 & 1 & 2,1 & 0 & 0,0 & 10 & 20,8 & \\
\hline \multirow[t]{2}{*}{5} & Risiko Sangat Tinggi & $0 \quad 0,0$ & 0 & 0,0 & 2 & 4,2 & 0 & 0,0 & 0 & 0,0 & 2 & 4,2 & \\
\hline & Total & 1122,9 & 19 & 39,6 & 17 & 35,4 & 1 & 2,1 & 0 & 0,0 & 48 & 100,0 & \\
\hline
\end{tabular}

Sumber Data: Hasil Olah Data SPSS versi 21, Tahun 2021

Dari tabel 11 dapat disimpulkan bahwa faktor pekerja yaitu beban kerja dan sikap memiliki hubungan terhadap LBP pada penenun di Galery Ulos Sianipar Medan.

\section{B. Pembahasan}

\section{a. Faktor Individu dengan LBP pada Penenun Galery Ulos Sianipar Medan}

Usia. Hasil penelitian pada Tabel 24 menunjukkan bahwa sebagian besar pekerja tenun usia 39-52 tahun mengalami nyeri ringan dan nyeri sedang. Analisis statistik menunjukkan p-value sebesar 0,003 $(\mathrm{p}<0,05)$, artinya ada hubungan usia dengan LBP pada penenun di Galery Ulos Sianipar Medan. Hasil penelitian ini sejalan dengan penelitian yang dilakukan (Ones et al., 2021), (Sitompul et al., 2012), (Harwanti et al., 2018) dan (Ramdan \& Sartika, 2019) yang menyatakan ada hubungan usia dengan keluhan LBP. (Tambun, 2012) dalam penelitiannya di Kelurahan Martimbang dan Kelurahan Kebun Sayur, Kota Pematang Siantar tahun 2012 menyatakan bahwa keluhan LBP pada pekerja tenun ulos didominasi oleh penenun dengan usia lebih dari 30 tahun.

Usia merupakan faktor yang memperberat terjadinya nyeri punggung bawah. Biasanya nyeri punggung bawah ini diderita oleh orang yang berusia lanjut karena adanya penurunan fungsi-fungsi tubuh terutama keadaan tulang yang tidak lagi elastis. Usia menjadi salah satu faktor risiko dikarenakan seiring dengan meningkatnya usia seseorang maka akan terjadi degenerasi pada tulang. Keadaan ini mulai terjadi ketika seseorang mulai berusia 30 tahun. Secara 
langsung, usia mempengaruhi kemampuan jasmani atau kekuatan otot seseorang. Dalam kaitannya dengan otot, keluhan nyeri pada otot mulai dirasakan pada usia kerja yaitu 25-65 (Ones et al., 2021).

Diketahui bahwa pekerjaan menenun melalui beberapa tahap pekerjaan mulai dari pembuatan benang (proses pemintalan kapas), pewarnaan (untuk mendapatkan warna), gatip (rangkaian grafis bercorak khusus), unggas (pencerahan benang), ani (benang yang sudah selesai diunggas), dan selanjutnya tonun (tenun) yaitu proses pembentukan benang yang sudah "diani" menjadi sehelai ulos. Hasil observasi ditemui pekerjaan tenun tersebut semuanya dilakukan dalam kondisi duduk. Bekerja dengan keadaan yang sangat tidak ergonomis, yaitu bekerja dalam posisi duduk dalam waktu yang lama. Penenun kerap membungkukkan punggungnya saat menenun dan tidak dalam posisi tegak sehingga hal itu berlanjut sekian lama dan menimbulkan nyeri pada punggung bagian bawah.

Menurut (Putri, 2019) menyatakan bahwa penenun dengan usia lebih dari 36 tahun rentan dengan keluhan MSDs, yang bisa disebabkan karena keadaan jasmani yang menurun seiring bertambahnya usia juga proses perbaikan di tubuh kita membutuhkan waktu lebih lama. pada umumnya keluhan otot skeletal mulai dirasakan pada usia kerja, yaitu 25-65 tahun. Keluhan pertama biasanya dirasakan saat memasuki umur 35 tahun dan tingkat keluhan akan semakin meningkat seiring bertambahnya umur. Hal tersebut terjadi karena pada umur setengah baya, kekuatan dan ketahanan otot seseorang mulai menurun sehingga risiko untuk terjadinya keluhan otot meningkat.

IMT. Dari hasil penelitian menunjukkan bahwa pekerja tenun di Galery Ulos Sianipar Medan sebagian besar memiliki IMT kurang dari 29 atau tidak berisiko mengalami nyeri punggung bawah ringan. Analisis statistik menunjukkan $\mathrm{p}$-value sebesar 0,044 $(\mathrm{p}<0,05)$, artinya ada hubungan indeks massa tubuh dengan LBP pada penenun di Galery Ulos Sianipar Medan. Meskipun indeks massa tubuh penenun tidak berisiko tetapi sebagian besar penenun mengalami nyeri punggung bawah meskipun ringan. Hal ini disebabkan seluruh penenun di Galery Ulos Sianipar Medan duduk dengan posisi tidak ergonomis yaitu kursi tidak memiliki sandaran. Hal ini menunjukkan bahwa posisi kerja yang tidak ergonomis berpengaruh terhadap terjadinya LBP pada penenun.

IMT merupakan salah satu faktor individu yang dapat menjadi faktor penyebab LBP. Hasil penelitian ini sejalan dengan penelitian yang dilakukan (Gaya, 2015) yang menyatakan bahwa faktor-faktor penyebab LBP dibagi menjadi tiga faktor, yaitu faktor pekerjaan, faktor individu, dan faktor lingkungan. Oleh karena itu IMT dapat menjadi penyebab LBP. (Dhammayanthi et al., 2020) menunjukkan bahwa index massa tubuh pengrajin kain tenun di Desa Sidemen Kecamatan Sidemen Kabupaten Karangasem pada tahun 2017 lebih banyak memiliki IMT $\leq 22,9$ atau tidak berisiko. Meskipun tidak ada 
hubungan, hasil penelitian (Sitompul et al., 2012) menunjukkan bahwa sebagian besar pengrajin songket di Desa Talang Aur dengan IMT normal mengalami keluhan nyeri pinggang.

Menurut (Natosba \& Jaji, 2016) menjabarkan sekitar 90\% dari seluruh kasus LBP disebabkan oleh faktor mekanik, yaitu LBP pada susunan anatomi wajar yang dipakai secara berlebihan atau akibat sekunder dari trauma atau deformitas, yang menimbulkan stress atau strain pada otot, tendon dan ligamen. Selain itu, dari segi anatomi dan fungsional, LBP juga bisa disebabkan karena adanya kelainan pada spine (ruas tulang belakang), dimana spine merupakan struktur penyangga tubuh dan kepala yang selalu terlibat dalam berbagai sikap tubuh dan gerakan sehingga mudah sekali mengalami gangguan.

Penelitian klinis sejak lama telah membuktikan bahwa kegemukan berpengaruh buruk terhadap kesehatan tubuh. Selain memicu penyakit metabolis, obesitas meningkatkan risiko kelainan musculoskeletal utamanya nyeri punggung bawah. Secara teori, berat badan berlebuh dapat menyebabkan peningkatan beban tubuh pada sendi penumpu tubuh, sehingga memungkinkan terjadinya nyeri pinggang. Perut yang membuncit ke depan karena gemuk atau dinding abdomen yang lemak akan menyebabkan strain yang kronik pada tulang vertebra sehingga akan menyebabkan keluhan nyeri pinggang. Kegemukan atau obesitas dapat menimbulkan nyeri punggung statik karena perubahan titik pusat badan. Tubuh akan berusaha menyesuaikan titik pusat badan, dengan pertambahan berat badan yang terjadi (Sitompul et al., 2012).

Lama Bekerja. Masa kerja menunjukkan lamanya seseorang terkena paparan di tempat kerja. Semakin lama masa kerja seseorang, semakin lama terkena paparan di tempat kerja sehingga semakin tinggi risiko terjadinya penyakit akibat kerja. Dari hasil penelitian menunjukkan bahwa sebagian besar pekerja tenun di Galery Ulos Sianipar yang bekerja lebih dari 10 tahun mengalami nyeri sedang. Analisis statistik menunjukkan p-value sebesar 0,022 $(\mathrm{p}<0,05)$, artinya ada hubungan lama bekerja dengan LBP pada penenun di Galery Ulos Sianipar Medan. Hasil penelitian ini sejalan dengan pernyataan (Ones et al., 2021), dan (Prastuti et al., 2020) bahwa masa kerja berisiko terhadap LBP dikarenakan akumulasi kegiatan kerja seseorang yang dilakukan dalam jangka waktu yang cukup panjang. Apabila kegiatan itu dilakukan terus-menerus dalam jangka waktu bertahun-tahun akan mengakibatkan gangguan pada tubuh. Tekanan lewat jasmani pada suatu kurun waktu tertentu dapat mengakibatkan berkurangnya kinerja otot. Tekanan-tekanan yang terakumulasi setiap hari pada suatu masa yang panjang, akan mengakibatkan memburuknya status kesehatan. Begitu pula sebaliknya penenun yang bermasa kerja baru, berisiko lebih rendah mengalami keluhan LBP.

Seseorang yang bekerja lebih dari lima tahun akan mengalami peningkatan risiko terjadinya LBP dibandingkan dengan pekerja yang masa kerjanya kurang dari lima tahun. Hal ini disebabkan karena seseorang dengan masa kerja lebih 
lama akan semakin lama terpapar faktor risiko LBP sehingga dapat secara permanen terkena LBP serta mengakibatkan degenerasi tulang belakang yang juga dipengaruhi oleh peningkatan usia kerja (Saputra, 2020). (Tafese et al., 2018) menjabarkan bahwa pekerja yang berpengalaman kerja lebih lama berpeluang dua sampai 10 kali untuk mengembangkan LBP terkait pekerjaan dibandingkan dengan mereka yang memiliki pengalaman kerja lebih pendek.

\section{b. Faktor Lingkungan Kerja dengan LBP pada Penenun Galery Ulos Sianipar} Medan

Durasi Kerja. Dari hasil penelitian menunjukkan bahwa sebagian besar pekerja tenun di Galery Ulos Sianiparbekerja lebih dari delapan jam perhari mengalami nyeri sedang. Analisis statistik menunjukkan p-value sebesar 0,020 $(\mathrm{p}<0,05)$, artinya ada hubungan durasi kerja dengan LBP pada penenun di Galery Ulos Sianipar Medan. (Dhammayanthi et al., 2020) menjelaskan bahwaada hubungan antara lama duduk terhadap LBP pada pengerajin kain tenun di Desa Sidemen. Pengrajin kain tenun yang duduk $>4$ jam berisiko 5,871 kali untuk mengalami nyeri punggung bawah dibandingkan yang duduk $<4$ jam. Umumnya penenun di Galery Ulos Sianipar Medan melakukan aktivitas menenun sampai dengan delapan jam dan bahkan ada juga yang mencapai 17,5 jam per hari. Meskipun ada waktu istirahat selama 60 menit, namun karena tuntutan perekonomian, sehingga penenun terus melakukan pekerjaan menenun mencapai 17,5 jam per hari dan berisiko tinggi mengalami LBP. Implikasinya, semakin lama bekerja dalam posisi tubuh yang statis, maka semakin tinggi risiko timbulnya keluhan LBP, tetapi ada juga penenun yang bekerja kurang dari delapan jam mengalami risiko tinggi timbulnya keluhan LBP.

Waktu Istirahat. Dari hasil penelitian menunjukkan bahwa pekerja tenun di Galery Ulos Sianipar sebagian besar beristirahat lebih dari 30 menit mengalami nyeri ringan. Analisis statistik menunjukkan p-value sebesar 0,018 $(\mathrm{p}<0,05)$, artinya ada hubungan waktu istirahat dengan LBP pada penenun di Galery Ulos Sianipar Medan. Hasil penelitian ini sejalan dengan pendapat (Dhammayanthi et al., 2020) kondisi lama duduk >4 jam menyebabkan lebih sering terjadi gangguan sehingga terjadi kelelahan dan iskemia jaringan di sekitar region tersebut. Regio nyeri yang luas dirasakan di sekitar vertebra lumbalis sehingga mempunyai risiko lebih besar untuk menjadi nyeri yang disebabkan oleh kondisi hiperalgesia. Sehingga disela-sela waktu bekerja harus istirahat selama 15-30\% dari lamanya waktu saat bekerja. Jika jam kerja melampaui dari yang seharusnya akan kondisi penurunan efektivitas kerja, gangguan kesehatan, angka absensi karena sakit meningkat, yang dapat mengakibatkan rendahnya tingkat produktivitas kerja.Tetapi hasil penelitian ini tidak sejalan dengan penelitian yang dilakukan (Sitompul et al., 2012) yang menyatakan tidak ada hubungan yang signifikan antara waktu istirahat dengan keluhan nyeri pinggang.

Pada penelitian ini sebagian besar penenun memiliki waktu istirahat lebih dari 30 menit, tetapi oleh penenun waktu istirahat dilakukan sesingkat mungkin 
hanya istirahat untuk makan saja, selebihnya penenun melakukan aktivitas menenun kembali. Seperti yang dilakukan penenun Surianemsi waktu istirahat yang digunakan hanya 20 menit dengan durasi kerja 12 jam sehari dan penenun Dahliana waktu istirahat yang digunakan 30 menit dengan durasi kerja 8,5 jam sehingga kurang memberikan waktu untuk relaksasi bagi tubuh.

Beristirahat merupakan salah satu upaya untuk menurunkan tingkat stress yang dialami oleh otot. Hal ini sesuai dengan teori bahwa pemberian istirahat yang cukup pada malam hari dapat mengembalikan performa kerja sehingga tidak terjadi penurunan hari berikutnya. Beberapa kondisi yang berperan sebagai faktor pencetus keluhan nyeri adalah pekerjaan yang memerlukan pengulangan gerakan otot secara berlebih, posisi canggung dengan tidak disertai waktu pemulihan yang tidak memadai (Tristiawan et al., 2019).

\section{Kesimpulan}

Berdasarkan hasil analisis dan pembahasan data, penulis dapat mengambil kesimpulan bahwa faktor individu yaitu umur $(\mathrm{p}=0,003)$, IMT $(\mathrm{p}=0,044)$ dan lama bekerja $(p=0,022)$; faktor lingkungan kerja yaitu durasi kerja $(p=0,020)$ dan waktu istirahat $(\mathrm{p}=0,018)$; dan faktor pekerjaan yaitu beban kerja $(\mathrm{p}=0,001)$ dan sikap kerja $(\mathrm{p}=0,001)$ memiliki hubungan dengan LBP pada penenun di Galery Ulos Sianipar Medan. 
Analisis Faktor-Faktor yang Berhubungan dengan Low Back Pain pada Penenun Galery Ulos Sianipar Medan

\section{BIBLIOGRAFI}

Abraha, T. H., Demoz, A. T., Moges, H. G., \& Ahmmed, A. N. (2018). Predictors of back disorder among Almeda textile factory workers, North Ethiopia. BMC Research Notes, 11(1). https: //link.springer.com/ content/pdf/10.1186/s13104018-3440-4.pdf. Google Scholar

American College of Physicians. (2019). Low Back Pain is prevalent among workers and may be underreported.

Anggraini, D. (2019). UMKM Ulos Binaan BI Tembus Rp1,5 Miliar per Bulan. Gatra. https: //www.gatra.com/detail/news/431380/ekonomi/umkm-ulos-binaan-bitembus-rp15-miliar-per-bulan.

Daswani, K. (2019). Preventing Low Back Pain Owning To Long Working Hours. Entrepreneur India. https: //www.entrepreneur.com/article/343113.

Dhammayanthi, I. A. D. Y., Purnamawati, S., \& Muliarta, M. (2020). Hubungan lama duduk terhadap nyeri punggung bawah miogenik dan faktor-faktor yang berhubungan pada pengerajin kain tenun di Desa Sidemen, Kecamatan Sidemen, Kabupaten Karangasem tahun 2017. Google Scholar

Duthey, B. (2013). Background paper 6.24 low back pain. Priority Medicines for Europe and the World. Global Burden of Disease (2010),(March), 1-29. Google Scholar

Gaya, L. L. (2015). Pengaruh Aktivitas Olahraga, Kebiasaan Merokok, dan Frekuensi Duduk Statis dengan Kejadian Low Back Pain. Jurnal Agromedicine, 2(2), 186189. Google Scholar

Greenough, C. (2016). The National Back Pain Pathway. Google Scholar

Harahap, P. S., Marisdayana, R., \& Al Hudri, M. (2019). Faktor-faktor yang berhubungan dengan keluhan Low Back Pain (LBP) pada pekerja pengrajin batik tulis di Kecamatan Pelayangan Kota Jambi Tahun 2018. Riset Informasi Kesehatan, 7(2), 147-154. Google Scholar

Harwanti, S., Ulfah, N., \& Nurcahyo, P. J. (2018). Faktor-faktor yang berpengaruh terhadap Low Back Pain (LBP) pada pekerja di home industri batik Sokaraja Kabupaten Banyumas. Jurnal Kesehatan Masyarakat, 10(02). Google Scholar

Istighfaricha, S. H. (2020). Mengenal Apa Itu Nyeri Punggung Bawah Atau Low Back Pain.

Jayamanggala, A. (2017). Low Back Pain.Diponogoro medical Journal. Google Scholar

Iker, K., \& Luckhaupt, S. E. (2019). Low Back Pain among Workers: The Problem and What to Do About It. https: //blogs.cdc.gov/niosh-science-blog/2019/07/08/lbp/ 
Evan Filemon, Gerry Silaban, Nurmaini

Labao, H. C., Faller, E. M., \& Bacayo, M. F. D. (2018). 'Aches and Pains' of Filipino migrant workers in Malaysia: a profile of work-related musculoskeletal disorders. Annals of Global Health, 84(3), 474. Google Scholar

Lambak, S. Bin. (2017). Lecture Note Occupational Health and Safety Management.

Munawarah, S., \& Segita, R. (2021). HUBUNGAN MASSA KERJA DAN SIKAP Kerja Terhadap Timbulnya Lbp Pada Penenun Di Pandai Sikek. Human Care Journal, 6(1), 69-74. Google Scholar

Nandi, N., \& Bhadra, B. (2018). Low back ache in working women of reproductive age group in an urban area. Journal of OBGYN, 5(1), 43-46. Google Scholar

Natosba, J., \& Jaji, J. (2016). Pengaruh Posisi Ergonomis terhadap Kejadian Low Back Pain Pada Penenun Songket di Kampung BNI 46. Jurnal Keperawatan Sriwijaya, 3(2), 8-16. Google Scholar

Nugraha, F. R., Respati, T., \& Rachmi, A. (2020). Faktor Risiko Nyeri Punggung Bawah pada Ibu Rumah Tangga. Jurnal Integrasi Kesehatan Dan Sains (JIKS). Google Scholar

Ones, M., Sahdan, M., \& Tira, D. S. (2021). Faktor yang Berhubungan dengan Keluhan Nyeri Punggung Bawah (Low Back Pain) pada Penenun di Desa Letneo Selatan Kecamatan Insana Barat Kabupaten Timor Tengah Utara. Media Kesehatan Masyarakat, 3(1), 72-80. Google Scholar

Prastuti, B., Sintia, I., \& Ningsih, K. W. (2020). Hubungan Lama Kerja dan Posisi Duduk Terhadap Kejadian Low Back Pain Pada Penjahit di Kota Pekanbaru. Jurnal Endurance: Kajian Ilmiah Problema Kesehatan, 5(2), 375-382. Google Scholar

Putri, D. (2019). Perbedaan Keluhan MSDs pada Pekerja Bengkel Las dengan atau tanpa Meja Kerja di Kota Lhokseumawe Tahun 2019. Google Scholar

Rachmat, N., Utomo, P. C., Sambada, E. R., \& Andyarini, E. N. (2019). Hubungan Lama Duduk dan Sikap Duduk terhadap Keluhan Nyeri Punggung Bawah pada Penjahit Rumahan Di Kecamatan Tasikmadu. Journal of Health Science and Prevention, 3(2), 79-85. Google Scholar

Ramdan, I. M., \& Sartika, D. (2019). Low Back Pain Among Samarinda Sarong's Traditional Weavers And Its Related Factors. Public Health of Indonesia, 5(1), 17. Google Scholar

Sandira, M. I. (2021). Apakah Nyeri Punggung Bawah boleh Dipijat? https: //www.klikdokter.com/info-sehat/read/3617140/apakah-nyeri-punggung-bawahboleh-dipijat. 
Analisis Faktor-Faktor yang Berhubungan dengan Low Back Pain pada Penenun Galery Ulos Sianipar Medan

Saputra, A. (2020). Sikap Kerja, Masa Kerja, dan Usia terhadap Keluhan LOW BACK PAIN Low Back Pain pada Pengrajin Batik. HIGEIA (Journal of Public Health Research and Development), 4(Special 1), 147-157. Google Scholar

Sastroasmoro, S., \& Ismael, S. (2016). Dasar-dasar metodologi penelitian klinis. Sagung Seto. Google Scholar

Sitompul, A. M. H., Sitorus, R. J., \& Hasyim, H. (2012). Faktor-Faktor yang Berhubungan dengan Keluhan Nyeri Pinggang pada Pengrajin Songket di Desa Talang Aur Kecamatan Indralaya Kabupaten Ogan Ilir. Jurnal Ilmu Kesehatan Masyarakat, 3(1). Google Scholar

Sugiyono, D. (2013). Metode penelitian pendidikan pendekatan kuantitatif, kualitatif dan $R \& D$. Google Scholar

Sundell, C. G., Bergström, E., \& Larsén, K. (2019). Low Back Pain and associated disability in Swedish adolescents. Scandinavian Journal of Medicine and Science in Sports, 29(3), 393-399. https: /onlinelibrary. wiley.com/doi/full/10.1111/sms.13335. Google Scholar

Suryati, Y., \& Nggarang, B. N. (2020). Analysis of Working Postures on the Low Back Pain Incidence in Traditional Songket Weaving Craftsmen in Ketang Manggarai Village, NTT. Journal of Epidemiology and Public Health, 5(4), 469-476. Google Scholar

Suzuki, H., Kanchiku, T., Imajo, Y., Yoshida, Y., Nishida, N., \& Taguchi, T. (2016). Diagnosis and characters of non-specific Low Back Pain in Japan: The Yamaguchi Low Back Pain study. PLoS ONE, 11(8), 1-13. https: //journals.plos.org/plosone/article?id=10.1371/journal.pone.0160454. Google Scholar

Syed, M. A., Azim, S. R., \& Baig, M. (2019). Frequency of orthopedic problems among patients attending an orthopedic outpatient department: a retrospective analysis of 23495 cases. Annals of Saudi Medicine, 39(3), 172-177. Google Scholar

Tafese, A., Kebede, G., Shibru, A., \& Benti, T. (2018). Work-Related Low Back Pain among Sewing Machine Operators of Garment Industry: Galan City Oromia Region, Ethiopia. International Journal of Occupational Hygiene, 10(1), 1-6. Google Scholar

Tambun, M. S. (2012). Analisis Risiko Ergonomi dan Keluhan Musculoskeletal Disorder (MSDs) pada Pekerja Tenun Ulos di Kelurahan Martimbang dan Kelurahan Kebun Sayur Kota Pematan Siantar Tahun 2012. Depok: Universitas Indonesia. Google Scholar

Tarwaka, S., \& Sudiajeng, L. (2004). Ergonomi untuk keselamatan, kesehatan kerja dan produktivitas. Uniba, Surakarta, 34-50. Google Scholar 
Tristiawan, N., Wahyuni, I., \& Jayanti, S. (2019). Analisis Faktor Risiko Keluhan Nyeri Punggung Bawah Menggunakan Software Catia Pada Pekerja Bagian Permesinan Di Umkm Saestu Makaryo, Pati. Jurnal Kesehatan Masyarakat (Undip), 7(1), 351-357. Google Scholar

Truong, N. (2020). Living with Lower Back Pain. Free Malaysia Today.

Wibowo, H. A. (2019). Low Back Pain (Sakit Punggung Bawah atau Boyok).

Wijayanti, F., \& Saftarina, F. (2019). Kejadian Low Back Pain (LBP) pada Penjahit Konveksi di Kelurahan Way Halim Kota Bandar Lampung. MEDULA, Medicalprofession Journal of Lampung University, 8(2), 82-88. Google Scholar

Yang, H., Haldeman, S., Lu, M.-L., \& Baker, D. (2016). LOW Low Back Pain prevalence and related workplace psychosocial risk factors: a study using data from the 2010 National Health Interview Survey. Journal of Manipulative and Physiological Therapeutics, 39(7), 459-472. Google Scholar

Zulfiani, D. (2019). Berburu Oleh-oleh di Galery Ulos Sianipar. https: //www.ceritajalan.com/2019/05/berburu-oleh-oleh-di-Galery -ulos.html.

\section{Copyright holder:}

Evan Filemon, Gerry Silaban, Nurmaini (2021)

\section{First publication right:}

Syntax Idea

This article is licensed under: 